\title{
KONSEP PROFESIONALITAS GURU PERSPEKTIF MASYARAKAT PESANTREN DI MADRASAH DINIYAH PONDOK PESANTREN MIFTAHUL ULUM LUMAJANG
}

\author{
Syuhud \\ Institut Agama Islam Syarifuddin Lumajang, Indonesia \\ E-mail: syuhudlu@gmail.com \\ Wiwin Sugianto \\ Institut Agama Islam Syarifuddin Lumajang, Indonesia \\ E-mail: wiwinsugianto1988@gmail.com
}

\begin{abstract}
Abstrak: Peningkatan kompetensi guru menentukan kualitas pengajarannya sekaligus kualitas pendidikannya. Berbagai upaya dilakukan untuk meningkatkan profesionalisme tersebut, misalnya dengan melakukan sertifikasi guru, mengadakan pelatihan dengan pembiayaan yang ditanggung pemerintah (continuous professional development), mengadakan program pendidikan profesi guru dan lain sebagainya. Penelitian ini ingin melihat bagaimana profesionalitas guru dalam perspektif masyarakat pesantren, dan bagaimana implementasi profesionalitas guru di Madrasah Diniyah Miftahul Ulum Jatiroto Lumajang. Adapun kesimpulan dari penelitian ini adalah konsep profesionalitas guru dalam perspektif masyarakat pesantren meliputi, kedewasaan bersikap, loyalitas tinggi dan pakar dalam bidang keilmuan agama. Loyalitas dan kepakaran menjadi hal yang paling urgen di madrasah diniyah berbasis pesantren. Loyalitas dapat muncul karena pesantren secara eksplisit membentuk karakter kepribadian santri sebagai orang yang taat kepada pimpinannya (baca; kiai). Begitu pula kepakaran, sekalipun tidak ada standar baku, pesantren memiliki distingsi tersendiri dalam menseleksi guruguru yang akan mengajar. Secara implementatif di madrasah diniyah Miftahul Ulum,profesionalismeguru dilakukan dengan upaya pembentukan Badan Pengelola Soal (BPS), penugasan guru terlebih dahulu dan membentuk kegiatan diklat halaqoh.
\end{abstract}

Kata Kunci: Profesionalitas Guru, Masyarakat Pesantren.

\section{Pendahuluan}

Islam sebagai agama universal memberikan pedoman dalam menjalani kehidupan bagi manusia menuju kebahagian di dunia dan akhirat, yang pencapaiannya sangat bergantung pada pendidikan. Oleh karena itu, Islam dan pendidikan sangat mempunyai hubungan yang sangat erat. Hubungan itu bersifat organis-fungsional; dimana pendidikan difungsikan sebagai alat untuk mencapai keislaman, dan Islam menjadi kerangka dasar serta pondasi pengembangan 
pendidikan Islam. ${ }^{1}$ Pendidikan merupakan suatu bimbingan atau pimpinan secara sadar oleh guru terhadap perkembangan jasmani dan rohani murid menuju terbentuknya kepribadian yang utama. ${ }^{2}$

Kini banyak pakar melakukan penelitian tentang persoalan pendidikan yang menghasilkan konsep-konsep baru untuk dilaksanakan dalam praktik pendidikan. Di Indonesia dalam setiap pergantian pemerintahan baru berimplikasi juga pada pergantian menteri terutama menteri Pendidikan dan Kebudayaan muncul gagasan baru tentang model pendidikan yang ideal bagi bangsa dan Negara.

Hal ini berlangsung akibat penyelenggaraan pendidikan yang lebih menitikberatkan pada aspek kuantitas dan kurang diimbangi dengan aspek kualitasnya. Peningkatan kualitas pendidikan ditentukan oleh peningkatan proses belajar-mengajar. Adanya peningkatan proses belajar-mengajar dapat meningkatkan kualitas lulusannya. Sedangkan peningkatan kualitas belajar-mengajar sangat bergantung pada kualitas guru dalam mengelola proses belajar-mengajar itu sendiri. Guru adalah pendidik, pasal 1 ayat (1) Undang-undang no 14 tahun 2005 tentang Guru dan Dosen, misalnya, menjelaskan bahwa guru adalah pendidik profesional dengan tugas utama. ${ }^{3}$

Dengan demikian, guru memegang peranan penting dalam proses belajarmengajar. Dalam proses interaksi belajar mengajar guru adalah orang yang membrikan pelajaran, dalam mentransfer pengetahuan kepada siswa diperlukan pengetahuan atau kecakapan atau keterampilan sebagai guru. ${ }^{4}$ Di pundaknya terpikul tanggung jawab utama keefektifan seluruh usaha kependidikan yang dilaksanakan di sekolah. Dalam pengertian bahwa profesionalitas guru memberikan arti penting terhadap kualitas produk pendidikan. Kendati masyarakat mulai dari yang terbelakang sampai pada yang paling maju mengakui bahwa guru merupakan satu di antara sekian banyak unsur pembentukan utama calon anggota masyarakat, bangsa dan Negara. Guru menempati peranan kunci dalam mengelola kegiatan proses belajar mengajar. Peranan kunci ini dapat diemban apabila ia memiliki tingkat kemampuan profesional

\footnotetext{
${ }^{1}$ Sarkowi, Labirin Pendidikan Islam (Malang: Resist Literacy, 2011), 7.

2 M. Ladzi Safroni, Al-Ghazali Berbicara Tentang Pendidikan Islam (Malang: Aditya Media, 2013), 79.

3 Dede Rosyada, Madrasah Dan Profesionalisme Guru (Depok: Kencana, 2017), 96.

${ }^{4}$ Syaiful Bahri Djamarah, Prestasi Belajar Dan Kompetensi Guru (Surabaya: Usaha Nasional, 1994), 32. 
yang tinggi yang tidak saja diukur dari kemampuan intelektual, melainkan juga dituntut untuk memiliki keunggulan dalam aspek moral, keimanan, ketaqwaan, tanggung jawab dan keluasan wawasan kependidikan dalam mengelola kegiatan pembelajaran. ${ }^{5}$

Upaya peningkatan kualitas pendidikan yang menitikberatkan pada profesionalitas guru juga dilakukan oleh Madrasah Diniyah Miftahul Ulum di bawah Pondok Pesantren Miftahul Ulum Banyuputih Kidul Jatiroto Lumajang. Beberapa di antaranya: memperketat rekrutmen guru, kualifikasi keilmuan, serta potensi-potensi yang dimiliki oleh calon guru, seperti fiqh, tafsir, hadits, dan sebagainya. Oleh karenanya, keseriusan pesantren ini yang meletakkan soal kualitas guru pada Madrasah Diniyah Miftahul Ulum menjadi alasan utama peneliti untuk menelitinya, sehingga penelitian ini dapat dijadikan bahan pertimbangan dan masukan serta rujukan dalam mengembangkan profesional guru.

\section{Kajian Tentang Definisi Guru}

Kata guru dalam bahasa Indonesia yang berarti mengajar. Dalam bahasa Inggris, dijumpai kata teacher yang berarti pengajar. ${ }^{6}$ Guru adalah spiritual father (baca: bapak rohani), bagi peserta didik yang memberikan santapan jiwa dengan ilmu, pembinaan akhlaq mulia dan meluruskan perilaku yang buruk. ${ }^{7}$

Guru adalah sosok yang digugu dan ditiru. Digugu artinya diindahkan atau dipercayai. Sedangkan ditiru artinya dicontoh atau diikuti. Ditilik dari bahasa aslinya, sansekerta, kata guru adalah gabungan dari kata gu dan ru. Gu artinya kegelapan sedangkan ru artinya melepaskan. Guru adalah orang yang berjuang terus menerus untuk melepaskan manusian dari kegelapan. ${ }^{8}$

Guru adalah pendidik yang menjalankan proses pembelajaran secara langsung bersama murid dan menjalankan fungsi-fungsi pendidikan lainnya untuk mencapai tujuan pendidikan sesuai keahlian dan kompetensi bidang yang dikuasainya.

\footnotetext{
${ }^{5}$ Ramayulis, Ilmu Pendidikan Islam (Jakarta: Kalam Mulia, 2010), 61.

${ }^{6}$ Jhon M Echol, Kamus Inggris Indonesia (Jakarta: Gramedia, 1982), 581.

${ }^{7}$ Sarkowi, Labirin Pendidikan Islam, 124.

${ }^{8}$ Hamka Abdul Aziz, Karakter Guru Profesional (Jakarta: AMP Press, 2016), 19.
} 
Menurut Undang-Undang Sistim Pendidikan Nasional dan PP. No. 32 Tahun 2013 tentang perubahan PP. No. 19 tahun 2005 tentang Standar Pendidikan Nasional, pendidik adalah tenaga kependidikan yang berkualifikasi sebagai guru, dosen, konselor, pamong belajar, widyaiswara, tutor, instruktur, fasilitator, dan sebutan lain yang sesuai dengan kekhususannya, serta berpartisipasi dalam menyelenggarakan pendidikan. ${ }^{9}$

Dalam Undang-undang No. 20 tahun 2003 tentang Sistem Pendidikan Nasional pasal 39 ayat 2, dinyatakan bahwa pendidik merupakan tenaga profesional yang bertugas merencanakan dan melaksanakan proses pembelajaran, menilai hasil pembelajaran, melakukan pembimbingan dan pelatihan serta melakukan penelitian dan pengabdian kepada masyarakat, terutama bagi pendidik pada perguruan tinggi. ${ }^{10}$

Guru merupakan jabatan atau profesi yang memerlukan keahlian khusus sebagai guru. ${ }^{11}$ Guru sebagai bagian dari sekolah merupakan sosok yang sangat membentuk kesuksesan program pendidikan. Dialah sosok yang langsung berinteraksi memberikan pengetahuan, keterampilan dan pemahaman kolektif kepada anak didik baik secara teori maupun praktik. ${ }^{12}$

Guru pada prinsipnya merupakan suatu profesi yang mempunyai keahlian tertentu, di mana masyarakat menempatkannya pada tempat yang lebih terhormat di lingkungannya, karena dari seorang guru diharapkan masyarakat dapat memperoleh ilmu pengetahuan. Hal ini berarti, guru berkewajiban mencerdaskan bangsa menuju pembentukan manusia seutuhnya berdasarkan karakter budaya bangsa. ${ }^{13}$

\section{Tugas Guru}

Tuntutan pencapaian tujuan pendidikan hanya dapat tercapai apabila seorang guru dapat melaksanakan tugasnya dengan baik. Diantara tugas guru diantaranya ialah:

\footnotetext{
${ }_{9}$ UU Sisdiknas No.32 Tahun 2013, Bab 1 Pasal 1 Ayat 6, 3.

10 UU Sisdiknas No.20 Tahun 2003, Pasal 39 Ayat 2, 5.

11 Moh. Uzer Usman, Menjadi Guru Profesional (Bandung: Remaja Rosdakarya, 1991), 3.

12 Jamal Ma'mur Asmani, Pendidikan Berbasis Keunggulan Lokal (Yogyakarta: Diva Press, 2012), 116.

${ }_{13}$ Nuni Yusvavera Syatra, Desain Relasi Efektif Guru Dan Murid (Yogyakarta: Buku Biru, 2013), 56. 
1. Tugas dalam bidang profesi, artinya suatu jabatan atau pekerjaan yang memerlukan keahlian khusus. Contoh: mendidik, melatih, dan mengajar untuk mentransferkan ilmu pengetahuan, mengembangkan nilai-nilai hidup, serta mengembangkan keterampilan anak didik.

2. Tugas dalam bidang kemanusiaan, artinya guru mencerminkan dirinya kepada anak didik sebagai orang tua kedua. Dengan demikian, anak didik tergugah mendapatkan perhatian yang terarah dan bergairah untuk belajar secara tekun.

3. Tugas dalam bidang kemasyarakatan, artinya guru hendaknya mampu menjadikan masyarakat yang berilmu pengetahuan, menuju pembentukan manusia seutuhnya. ${ }^{14}$

\section{Profesionalitas Guru}

Berbicara tentang kerja yang profesional mengharuskan kita untuk mengetahui terlebih dahulu pengertian profesi sebagai bentuk dasar kata profesional tersebut.Dalam kamus besar Bahasa Indonesia dijelaskan pengertian profesi adalah bidang pekerjaan yang dilandasi pendidikan keahlian. ${ }^{15}$

Merupakan sebuah keseluruhan antara kemampuan keilmuan teoretik, kemampuan praktis, integritas personal, akseptabilitas sosial, dan bahkan kebanggaan terhadap profesi yang diketahui. ${ }^{16}$

Menurut Liliana Tedjosaputro yang dikutip oleh Supriadi agar suatu lapangan kerja dapat dikategorikan profesi, diperlukan:

1. Pengetahuan

2. Penerapan keahlian

3. Tanggung Jawab

4. Self Control

5. Pengakuan oleh masyarakat. ${ }^{17}$

Kata Profesional berasal dari kata sifat yang berarti pencaharian dan sebagai kata benda yang berarti orang yang mempunyai keahlian seperti guru, dokter, hakim

14 Syatra, Desain Relasi Efektif Guru dan Murid (Jakarta: Grafindo Persada), 61.

${ }^{15}$ Kamus Besar Bahasa Indonesia, 789.

16 Dede Rosyada, Madrasab Dan Profesionalisme Guru (Depok: Kencana, 2017), 283.

${ }^{17}$ Supriadi, Etika Dan Tanggung Jawab Profesi Hukum di Indonesia (Jakarta: Sinar Grafika, 2006), 16. 
dan sebagainya. Dengan kata lain pekerjaan yang bersifat profesional adalah pekerjaan yang hanya dapat dilakukan oleh mereka yang khusus dipersiapkan untuk itu dan bukan pekerjaan yang dilakukan oleh mereka yang karena tidak dapat memperoleh pekerjaan lain.

Adapun kata profesionalitas berasal dari kata bahasa Inggris professionalism yang secara leksikal berarti sifat profesional. Sifat yang dimaksud adalah seperti yang dapat ditampilkan dalam perbuatan, bukan yang dikemas dalam kata-kata yang diklaim oleh pelaku secara individual.

\section{Ciri-ciri profesi}

1. Suatu bidang yang terorganisir dari jenis intlektual yang terus menerus dan berkembang dan diperluas.

2. Suatu teknis intlektual.

3. Suatu priode jenjang untuk pelatihan dan sertifikasi.

4. Penerapan praktis dari teknis intlektual dari urusan praktis.

5. Beberapa standart dan pernyatan tentang etika yang dapat diselenggarakan.

6. Kemampuan memberi kepemimipinan pada profesi sendiri.

7. Asosiasi dari anggota profesi yang menjadi suatu kelompok yang akrab dengan kualitas komunikasi yang tinggi antara anggota.

8. Pengakuan sebagai profesi.

9. Perhatian yang profesional terhadap pengguna yang bertanggung jawab dari pekerjaan profesi.

10. Hubungan erat dengan profesi lain. ${ }^{18}$

\section{Prinsip Profesionalitas}

Dalam Undang-undang Guru dan Dosen bab 3 pasal 7 ayat 1 tentang prinsip profesional menjelaskan profesi guru dan profesi dosen merupakan bidang pekerjaan khusus yang dilakukan berdasarkan prinsip sebagai berikut: ${ }^{19}$

1. Memiliki bakat, minat, panggilan jiwa, dan idealisme.

18 Supriadi, Tanggung Jawab Profesi (Jakarta: Sinar Grafika, 2006), 18.

${ }_{19}$ UU Guru dan Dosen No. 14 Tahun 2005, Bab 3 Pasal 7 Ayat 1.

154 | Tarbiyatuna: Jurnal Pendidikan Islam; Volume 11, Nomor 2, Agustus 2018 p-ISSN: 2085-6539; e-ISSN: 2242-4579 
2. Memiliki komitmen untuk meningkatkan mutu pendidikan, ketakwaan, dan akhlaq mulia.

3. Memiliki kualifikasi akademik dan latar belakang pendidkan sesuai dengan bidng tugas.

4. Memiliki kompetensi yang diperlukan sesuai dengan bidang tugas.

5. Memiliki tanggung jawab atas pelaksanaantugas keprofesionalan.

6. Memperoleh penghasilan yang ditentukansesuai dengan prestsi kerja.

7. Memilki kesempatan untuk mengembangkan profesionalisme secara berkelanjutan dengan belajar sepanjang hayat.

8. Memiliki jaminan perlindungan hukum dalam melaksanakan tugas keprofesionalan.

9. Memiliki organisasi profesi yang memiliki kewenangan mengatur hal-hal yang berkaitan dengan tugas keprofesionalan guru.

Dalam ayat 2 menyebutkan pemberdayaan profesi guru atau pemberdayaan profesi dosen diselenggarakan melalui pengembangan diri yang dilakukan secara demokratis, berkeadilan, tidak diskriminatif, dan berkelanjutan dengan menjunjung tinggi hak asasi manusia, nilai keagamaan, nilai kultural, kemajmuan bangsa, dan kode etik profesi. $^{20}$

\section{Kualifikasi Guru}

Menurut Undang-undang republik Indonesia No. 14 tahun 2005 bab 4 pasal 8 tentang kualifikasi menjelaskan bahwasanya guru wajib memiliki kualifikasi akademik, kompetensi, sertifikat pendidik, sehat jasmani dan rohani, serta memiliki kemampuan untuk mewujudkan tujuan pendididkan nasional. ${ }^{21}$

Dalam pasal 9 menyebutkan kualifikasi akademik sebagaimana dimaksud dalam pasal 8 diperoleh melalui pendidikan tinggi program sarjana atau program diploma empat. ${ }^{22}$

Dalam peraturan menteri pendidikan nasional republik Indonesia No 16 Tahun 2007 tentang standar kualifikasi akademik dan kompetensi guru pasal 1 ayat

${ }^{20}$ UU Guru dan Dosen No.14 Tahun 2005, Bab 3 Pasal 7 Ayat 1.

21 UU Guru dan Dosen No.14 Th. 2005. BAB IV Pasal 8.

22 UU Guru dan Dosen No.14 Th. 2005. BAB IV Pasal 9. 
1 menyatakan setiap guru wajib memenuhi standar kualifikasi akademik dan kompetensi guru yang berlaku secara nasional. Ayat 2 menyatakan standar kualifikasi akademik dan kompetensi guru sebagai mana dimaksud ayat 1 tercantum. ${ }^{23}$

\section{Kualifikasi Akademik}

Kualifikasi akademik guru pada satuan pendidikan jalur formal mencakup kualifikasi akademik guru pendidikan Anak Usia Dini/ Taman Kanakkanak/Raudatul Atfal (PAUD/TK/RA), guru sekolah dasar/Madrasah Ibtidaiyah (SD/MI), guru sekolah menengah pertama/madrasah Tsanawiyah (SMP/MTs), guru sekolah menengah atas/madrasah aliyah (SMA/MA), guru sekolah dasar luar biasa/sekolah menengah luar biasa/sekolah menengah atas luar biasa (SDLB/SMPLB/SMALB), dan guru sekolah menengah kejuruan/madrasah aliyah kejuruan (SMK/MAK), sebagai berikut.

1. Kualifikasi Akademik Guru PAUD/TK/RA Guru pada PAUD/TK/RA harus memiliki kualifikasi akademik pendidikan minimum diploma empat (D-IV) atau sarjana (S1) dalam bidang pendidikan anak usia dini atau psikologi yang diperoleh dari program studi yang terakreditasi.

2. Kualifikasi Akademik Guru SD/MI Guru pada SD/MI, atau bentuk lain yang sederajat, harus memiliki kualifikasi akademik pendidikan minimum diploma empat (D-IV) atau sarjana (S1) dalam bidang pendidikan SD/MI (D-IV/S1 PGSD/PGMI) atau psikologi yang diperoleh dari program studi yang terakreditasi.

3. Kualifikasi Akademik Guru SMP/MTs Guru pada SMP/MTs, atau bentuk lain yang sederajat, harus memiliki kualifikasi akademik pendidikan minimum diploma empat (D-IV) atau sarjana (S1) program studi yang sesuai dengan mata pelajaran yang diajarkan/diampu, dan diperoleh dari program studi yang terakreditasi.

4. Kualifikasi Akademik Guru SMA/MA Guru pada SMA/MA, atau bentuk lain yang sederajat, harus memiliki kualifikasi akademik pendidikan minimum

${ }^{23}$ Peraturan Menteri Pendidikan Nasional Republik Indonesia No. 16 Tahun 2007. 
diploma empat (D-IV) atau sarjana (S1) program studi yang sesuai dengan mata pelajaran yang diajarkan/diampu, dan diperoleh dari program studi yang terakreditasi.

5. Kualifikasi Akademik Guru SDLB/SMPLB/SMALB Guru pada SDLB/SMPLB/SMALB, atau bentuk lain yang sederajat, harus memiliki kualifikasi akademik pendidikan minimum diploma empat (D-IV) atau sarjana (S1) program pendidikan khusus atau sarjana yang sesuai dengan mata pelajaran yang diajarkan/diampu, dan diperoleh dari program studi yang terakreditasi.

6. Kualifikasi Akademik Guru SMK/MAK Guru pada SMK/MAK atau bentuk lain yang sederajat, harus memiliki kualifikasi akademik pendidikan minimum diploma empat (D-IV) atau sarjana (S1) program studi yang sesuai dengan mata pelajaran yang diajarkan/diampu, dan diperoleh dari program studi yang terakreditasi.

7. Kualifikasi Akademik Guru Melalui Uji Kelayakan dan Kesetaraan

Kualifikasi akademik yang dipersyaratkan untuk dapat diangkat sebagai guru dalam bidang-bidang khusus yang sangat diperlukan tetapi belum dikembangkan di perguruan tinggi dapat diperoleh melalui uji kelayakan dan kesetaraan. Uji kelayakan dan kesetaraan bagi seseorang yang memiliki keahlian tanpa ijazah dilakukan oleh perguruan tinggi yang diberi wewenang untuk melaksanakannya.

\section{Kompetensi Guru}

Dalam Undang-undang Republik Indonesia No. 14 tahun 2005 bab 4 pasal 9 tentang kompetensi, bahwasanya kompetensi guru sebagai mana dimaksud adalah kompetensi pedagogik, kompetensi kepribadian, kompetensi sosial, dan kompetensi profesional yang diperoleh melalui pendidikan profesi. ${ }^{24}$

Kompetensi merupakan suatu kemampuan yang mutlak dimiliki guru agar tugasnya sebagai pendidik dapat terlaksana dengan baik. Beranjak dari pengertian inilah kompetensi merupakan suatu hal yang tidak bisa dipisahkan dari kegiatan

${ }^{24}$ UU Guru dan Dosen No. 14 Th. 2005. BAB IV Pasal 10 Ayat 1. 
pendidikan dan pengajaran. Agar memiliki pemahaman yang jelas tentang kompetensi ini. ${ }^{25}$ Berikut kompetensi yang harus dimiliki oleh seorang guru:

\section{Kompetensi Pedagogik}

Kemampuan mengelola pembelajaran peserta didik yang meliputi pemahaman terhadap peserta didik, rancangan dan pelaksanaan pembelajaran, evaluasi hasil belajar dan pengembangan pesrta didik untuk mengaktualisasikan berbagai potensi yang dimilikinya. ${ }^{26}$

\section{Kompetensi Kepribadian}

Keseluruhan dari individu yang terdiri dari unsur psikis dan fisik. Dalam makna yang demikian maka seluruh sikap dan perbuatan seseorang merupakan suatu gambaran dari kepribadian orang itu. $^{27}$

\section{Kompetensi Profesional}

Penguasaan seorang guru terhadap materi ajar sekurangnya mencakup penguasaan enam aspek materi ajar, yaitu fakta, konsep, prinsip, keterampilan, pemecahan masalah dan proses.

\section{Kompetensi Pengembangan Kurikulum}

Tugas utama seorang guru dalam mengembangkan kurikulum adalah menyiapkan dan mengembangkan bahan-bahan yang menjadi acuan dalam proses pembelajaran siswa.

\section{Kompetensi Penelitian}

Guru dituntut untuk selalu meng-update pengetahuannya, baik tentang proses pembelajaran baik konten bahan ajar. Oleh sebab itu para guru dianjurkan melakukan penelitian yang tidak menganggu pelaksanaan tugas mereka, yakni penelitian yang bisa dilakukan dalam pelaksanaan tugasnya sebagai guru ${ }^{28}$.

\section{Kompetensi Sosial}

Setiap guru harus memiliki kompetensi sosial yang baik, berkomunikasi dan bergaul dengan peserta didik, berkomunikasi dan bergaul dengan kolega,

\footnotetext{
${ }^{25}$ Syaiful Bahri Djamarah, Prestasi Belajar Dan Kompetensi Guru (Surabaya: Usaha Nasional, 1994), 32.

26 Mulyasa, Menjadi Guru Profesional (Bandung: Remaja RosdaKarya, 2006), 75.

${ }^{27}$ Syaiful Bahri, Prestasi Belajar, 58.

${ }_{28}^{8}$ Dede Rosyada, Madrasah Dan Profesionalisme Guru (Depok: Kencana, 2017), 217. 
berkomunikasi dan bergaul dengan masyarakat, menarik, empati, kolaboratif, suka menolong, menjadi panutan, komunikatif dan kooperatif.

\section{Pandangan Tentang Pesantren}

Berbicara pesantren sangat identik dengan lembaga pendidikan Islam. Sebagai wahana pendidikan Islam maka di dalamnya terjadi proses pendidikan yang mau tidak mau akan melibatkan berbagai faktor yang saling terkait dan menunjang tercapainya tujuan.

Dalam Peraturan Menteri Agama satuan pendidikan muadalah pada pondok pesantren pondok pesantren bab 1 Pasal 1 berbunyi

1. Satuan pendidikan muadalah pada pondok pesantren yang selanjutnya disebut satuan pendidikan muadalah adalah satuan pendidikan keagamaan Islam yang diselenggarakan oleh dan berada di lingkungan pesantren dengan mengembangkan kurikulum sesuai kekhasan pesantren dengan basis kitab kuning atau dirasah islamiyah dengan pola pendidikan muallimin secara berjenjang dan terstruktur yang dapat disetarakan dengan jenjang pendidikan dasar dan menengah di lingkungan Kementerian Agama.

2. Pendidikan keagamaan Islam adalah pendidikan yang mempersiapkan peserta didik untuk dapat menjalankan peranan yang menuntut penguasaan pengetahuan ten tang ajaran agama Islam dan atau menjadi ahli ilmu agama Islam dan mengamalkan ajaran agama Islam.

3. Pondok pesantren yang selanjutnya disebut pesantren adalah lembaga pendidikan keagamaan Islam yang diselenggarakan oleh masyarakat yang menyelenggarakan satuan pendidikan pesantren dan atau secara terpadu menyelenggarakan jenis pendidikan lainnya.

4. Kitab kuning adalah kitab keislaman berbahasa Arab yang menjadi rujukan tradisi keilmuan Islam di pesantren.

5. Dirasah Islamiyah adalah kumpulan kajian tentang ilmu agama Islam yang tersusun secara sistematik, terstruktur, dan terorganisasi. 
6. Pola pendidikan mu'allimin adalah sistem pendidikan pesantren yang bersifat integratif dengan memadukan ilmu agama Islam dan ilmu umum dan bersifat komprehensif dengan memadukan intra, ekstra dan kurikuler.

7. Kurikulum adalah seperangkat rencana dan pengaturan mengenai tujuan, isi, bahan pelajaran, dan cara yang digunakan sebagai pedoman penyelenggaraan kegiatan pembelajaran untuk mencapai tujuan pendidikan tertentu.

8. Evaluasi pendidikan adalah kegiatan pengendalian, penjaminan, dan penetapan mutu pendidikan terhadap berbagai komponen pendidikan pada pendidikan diniyah dan pesantren sebagai bentuk pertanggungjawaban penyelenggaraan pendidikan.

9. Akreditasi adalah kegiatan penilaian kelayakan program dan atau satuan pendidikan berdasarkan kriteria yang telah ditetapkan.

10. Badan Standar Nasional Pendidikan yang selanjutnya disebut BSNP adalah badan mandiri dan independen yang bertugas mengembangkan, memantau, dan mengendalikan standar nasional pendidikan. ${ }^{29}$

11. Menteri adalah Menteri Agama.

12. Direktur Jenderal adalah Direktur Jenderal Pendidikan Islam.

\section{Definisi dan Karateristik Pesantren}

Pesantren adalah lembaga pendidikan tradisional yang lahir dan tumbuh berbarengan dengan datangnya Islam ke tanah Jawa. Dengan demikian, pesantren merupakan lembaga pendidikan tertua dan asli (indegenous) di masyarakat Indonesia. ${ }^{30}$

Sebagai lembaga pendidikan Islam tradisional, ditengarai merupakan kelanjutan dari sistem pendidikan pada masa Hindu-Budha pra-Islam. Dengan demikian, pesantren selain identik dengan makna keislaman juga makna keaslian Indonesia, sehingga Islam, pada saat itu, tinggal meneruskan dan mengislamkan lembaga pendidikan yang sudah ada. ${ }^{31}$

Sebagai sebuah sistem pendidikan yang merupakan kelanjutan dari sistem pendidikan sebelumnya, pesantren berhasil memadukan sistem pendidikan Islam

29 Peraturan Menteri Agama Republik Indonesia Nomor 18tahun 2014 pasal 1.

${ }^{30}$ Manfred Ziemik, Pesantren Dalam Perubahan Sosial (Jakarta: P3M, 1986), 100.

${ }_{11}$ Nurcholish Madjid, Bilik-Bilik. Pesantren Sebuah Potret Perjalanan (Jakarta: Paramadina, 1997), 3. 
yang di dalamnya diajarkan ajaran Islam dengan budaya lokal yang mengakar pada saat itu. Upaya pemaduan antara ajaran Islam dengan budaya lokal itu, merupakan ciri penyebaran Islam pada masa awal Islam, yang mengutamakan kelenturan dan toleransi terhadap keyakinan dan nilai-nilai yang hidup subur di masyarakat sejak sebelum Islam datang ke Nusantara. ${ }^{32}$

Dari gambaran di atas, jelaslah bahwa pesantren yang merupakan lembaga pendidikan di Indonesia, yang tumbuh dan berkembang sejak ratusan tahun lalu masih eksis dan dibutuhkan kehadirannya di tengah-tengah masyarakat Muslim Indonesia.

Namun demikian, eksistensi pesantren sebagai lembaga pendidikan Islam di Indonesia mendapat berbagai tantangan dan rintangan. Mulai pada masa kolonial Belanda, masa kemerdekaan, masa Orde Baru hingga masa sekarang, pesantren mendapat tekanan yang tidak ringan. Tantangan pertama datang dari sistem pendidikan yang dilancarkan oleh pemerintah kolonial Belanda, yang memperkenalkan sistem pendidikan sekolah bagi anak-anak di Indonesia, dengan mendirikan Sekolah Rakyat (volkscholen) atau disebut juga sekolah desa (nagari) dengan masa belajar 3 tahun. ${ }^{33}$

Pesantren merupakan lembaga pendidikan dan pengajaran Islam di mana di dalamnya terjadi interaksi antara kiai atau ustadz sebagai guru dan para santri sebagai murid dengan mengambil tempat dimasjid atau dihalaman-halaman asrama untuk mengaji dan membahas buku-buku keagamaan karya ulama masa lalu. Buku-buku teks ini lebih dikenal dengan sebutan kitab kuning, karena dimasa lalu kitab-kitab itu pada umumnya dicetak diatas kertas berwarna kuning. Hingga sekarang penyebutn itu tetap lestari walaupun banyak diantaranya yang dicetak ulang dengan menggunakan kertas putih. Dengan demikaian unsur terpenting bagi sebuah pesantren adalah adanya kiai, para santri, masjid,tempat tinggal (pondok) serta bukubuku atau kitab-kitab kuning. ${ }^{34}$

\section{Sistem Pendidikan Pesantren}

32 Suteja, Pola Pemikiran Kaum Santri (Bandung: Pustaka Hidayah, 1999), 77.

33 Azyumardi Azra, Pesantren Kontinuitas dan Perubahan (Jakarta: Nirmana Media), 12.

34 Maksum, Pola Pembelajaran di Pesantren (Jakarta: Departemen Agama, 2003), 3. 
Bila kita menggunakan istilah sistem pendidikan atau pengajaran pondok pesantren adalah saran atau berupa perangkat organisasi yang diciptakan untuk mencapai tujuan pendidikan yang berlangsung di pondok pesantren. Sedangkan bila mempergunakan istilah sistim pendekatan tentang metode pengajaran agama Islam di Indonesia, maka pengertiannya adalah cara pendekatan dan penyampaian ajaran agama Islam di Indonesia dalam ruang lingkup yang luas, tidak hanya terbatas pada pondok pesantren, tetapi mencakup lembaga-lembaga pendidikan formal, baik madrasah maupun sekolah umum dan non formal. ${ }^{35}$

Sistim pendidikan tradisional muslim pada dasarnya merupakan sistim pendidikan yang menerapkan metode intelektual yang merujuk pada metode intelektual yang telah diwariskan generasi-generasi Islam pada abad pertengahan hijriyah yang telah mengalami polarisasi dan kristalisasi sebagai konsekwensi logis penyebaran dan perkembangan Islam melewati berbagai bentuk peradaban dan budaya dunia. ${ }^{36}$

\section{Tipologi Pesantren}

Pada dasarnya pesantren didirikan untuk mencetak para ulama' atau para ahli dalam bidang agama Islam. Menurut Hasbullah, Pesantren merupakan 'bapak' dari pendidikan Islam di Indonesia. Pesantren dilahirkan atas kesadaran kewajiban dakwah Islamiyah, yakni menyebarkan dan mengembengkan ajaran Islam, sekaligus mencetak kader-kader ulama' atau da'i. ${ }^{37}$

Dari berbagai tingkat konsistensi dengan sistem lama dan berpengaruh pada dan keterpengaruhan dengan sistem modern, secara garis besar pondok pesantren dapat dikategorikan ke dalam tiga bentuk, yaitu: Pondok Pesantren Salafiyah, Pondok Pesantren Kholafiyah, dan Pondok Pesantren Campuran /Kombinasi.

Pendidikan yang yang berkembang di pesantren, sangat menekankan aspek keteladanan, khususnya dari sang kiai. Ini sungguh mencerminkan konsep pendidikan Islam. Hal kedua yang menjadi ciri khas sekaligus keunggulan pesantren, adalah

\footnotetext{
35 Djamaludin, Kapita Selekta Pendidikan Islam (Bandung: CV. Pustaka Setia, 1999), 114.

36 Rohiah M Noor, KH Hasyim Asy'ari Memodernisasi NU \& Pendidikan Islam (Jakarta: Grafindo Khazanah Ilmu, 2010), 56.

${ }^{37}$ Hasbullah, Sejarah Pendidikan Islam di Indonesia (Jakarta: Raja Grafindo Persada, 1999), 138.
} 
dukungan lingkungan. Lebih jauh dari itu kelebihan pesantren adalah memiliki semua yang baik.

\section{Masyarakat Pesantren}

Masyarakat pesantren yang dimaksud dalam penelitian ini adalah seluruh individu yang ada di dalam pesantren yang memiliki kepentingan langsung dalam pelaksanaan pendidikan yang dilakukan oleh pesantren. Dalam hubungannya dengan elemen pesantren, di mana kiai dan santri merupakan bagianterpenting dari pelaksanaan pendidikan di pesantren, peran pengurus pesantren dan guru atau asatidz juga memiliki peran dan kedudukan penting dalam pelaksanaan pendidikan di pesantren.

\section{Metodologi}

Penelitian ini menggunakan metode penelitian kualitatif yaitu prosedur penelitian yang menghasilkan data diskriptif dengan pendekatan fenomenologis yang berarti suatu penelitian yang berusaha memahami arti peristiwa dan kaitannya terhadap orang-orang biasa dalam situasi tertentu. ${ }^{38}$ Teknik pengumpulan data yang digunakan observasi, ${ }^{39}$ wawancara, ${ }^{40}$ dan dokumentasi. ${ }^{41}$ Penelitian dilakukan di Madrasah Diniyah Miftahul Ulum Banyuputih Kidul Jatiroto Lumajang, pada bulan April tahun 2018.

\section{Konsep Profesionalitas Guru dalam Perspektif Masyarakat Pesantren di}

\section{Madrasah Diniyah Miftahul Ulum Banyuputih Kidul Jatiroto Lumajang}

Sosok guru profesional menurut masyarakat pesantren setelah peneliti melakukan wawancara adalah guru yang bersikap dewasa. Sikap dewasa mengandung makna banyak hal. Di antaranya teladan, sabar, disiplin, bijak dalam mengambil keputusan, dan lain sebagainya.

\footnotetext{
${ }^{38}$ Lexy J Moeleong, Metode penelitian kualitatif (Bandung: Remaja Rosda Karya Offest, 1994), 42.

${ }^{39}$ Kartono kartini, Metodologi Penelitian Sosial (Bandung: Bumi Aksara, 1996), 157.

40 Margono, S, Metodologi Penelitian Pendidikan (Jakarta: Rineka Cipta, 2000), 79.

${ }^{41}$ Suharsimi Arikunto, Prosedur Penelitian (Jakarta: PT. Rineka Cipta, 2003), 234.
} 
Zainuddin, mengatakan bahwa sosok guru profesional adalah guru yang disiplin. Disiplin dalam segala hal. ${ }^{42}$ Guru di madrasah diniyah ini harus menjadi teladan bagi santri, dikarenakan kedewasaan bersikap mereka. Kedewasaan bersikap yang dipandang oleh masyarakat pesantren merupakan sosok guru profesional. Setidaknya dua hal yang harus dimiliki oleh guru di Madrasah Diniyah Miftahul Ulum, yakni:

\section{Loyalitas tinggi}

Loyalitas tinggi merupakan santri maupun alumni yang berprofesi sebagai guru di madrasah diniyah Miftahul Ulum tanpa digaji atau dapat juga dikatakan sebagai pengabdian. Dalam mengajar diniyah, guru tidak pernah berfikir tentang gaji, seperti pekerjaan lainnya. Karena mengajar di madrasah diniyah merupakan amal menuju akhirat. ${ }^{43}$ Jauhari, wakil kepala madrasah diniyah Miftahul Ulum juga menyampaikan bahwa semua guru yang mengajar fokus pada pengabdian. Meskipun ada penghargaan beruda honor, hanya sebatas rasa terima kasih dari madrasah dan itu bukan gaji. ${ }^{44}$

Samsul dalam wawancaranya, beliau mengatakan bahwasannya:

"jika mengajar diniyah harapan kita adalah akhirat bukan yang lain, dan madrasah diniyah insya Allah lebih kompak dari pada lembaga pada umumnya. Menurut saya pribadi, karena tidak ada unsur duniawi yang dibuat saling iri, seperti halnya uang. Semua basis dasarnya adalah pengabdian." 45

\section{Pakar keilmuan}

Pakar keilmuan adalah fokus terhadap disiplin ilmu tertentu sesuai dengan bidang masing-masing, sehingga para guru di madrasah diniyah Miftahul ulum terfokus pada pelajaran yang dibidangi saja.

Sesuai dengan hal yang dikatakan oleh Zainuddin kepala madrasah diniyah Miftahul Ulum Lumajang mengatakan:

"pakar keilmuan yang dimaksud disini adalah ustadz itu benar-benar menguasai betul tentang pelajaran yang dibidanginya. Seperti pelajaran Fathul

\footnotetext{
42 Zainuddin, Wawancara, KepalaMadrasah Diniyah Miftahul Ulum, Rabu 18 April 2018.

43 Mukhlis, Wawancara, UstadzMadrasah Diniyah Miftahul Ulum, Kamis 19 April 2018.

${ }^{44}$ Jauhari, Wawancara, Wakil Kepala Madrasah Diniyah Miftahul Ulum, Senin, 16 April 2018.

${ }^{45}$ Samsul, Wawancara, Sekretaris Madrasah Diniyah Miftahul Ulum, Senin, 16 April 2018. 
Qorib, maka dia harus faham betul pelajaran itu karena memang sudah bidangnya. Ia harus pernah belajar dan tuntas dalam belajarnya. Tuntas maksudnya adalah lulus dalam ujiannya." 46

Hal yang sama juga dikatakan oleh Mukhlis, salah satu guru di madrasah diniyah Miftahul Ulum Lumajang. Ia menuturkan bahwa ketika seorang guru menekuni sesuai dengan bidangnya, maka pembelajarannya pun pasti akan maksimal. ${ }^{47}$

\section{Implementasi Professionalitas Guru di Madrasah Diniyah Miftahul Ulum Banyuputih Kidul Jatiroto Lumajang.}

Madrasah Diniyah Miftahul Ulum Banyuputih Kidul Jatiroto adalah madrasah yang berada di bawah Pondok Pesantren Miftahul Ulum, pengelolaannya dilakukan oleh Yayasan Pondok Pesantren Miftahul Ulum (YPPMU). Madrasah Diniyah merupakan unit madrasah yang paling 'bergengsi' dari pada lembaga yang lain di bawah Pondok Pesantren Miftahul Ulum, baik Madrasah Aliyah formal maupun Madrasah Tsanawiyah Formal. Dikatakan paling bergengsi karena lembaga madrasah diniyah Miftahul Ulum merupakan lembaga yang paling disegani santri dan lembaga yang paling ketat. Unit lembaga ini juga unit prioritas yang dikembangkan di Pondok Pesantren Miftahul Ulum Jatiroto Lumajang. ${ }^{48}$

Berikut langkah-langkah yang dilakukan oleh Madrasah Diniyah Miftahul Ulum Jatiroto Lumajang:

\section{Adanya pembentukan fan pelajaran}

Fan pelajaran adalah sebuah mata pelajaran pemfokusan, di mana seorang guru diletakkan pada bidangnya masing-masing. Untuk mengetahui bidang yang dimampu seorang guru, Madrasah melakukan tes wawancara terlebih dahulu kemudian pondok pesantren mengadakan program diklat halaqoh.

\footnotetext{
46 Zainuddin, Wawancara, KepalaMadrasah Diniyah Miftahul Ulum, Kamis, 19 April 2018.

${ }^{47}$ Mukhlis, Wawancara, Pengajar Madrasah Diniyah Miftahul Ulum, Selasa, 17 April 2018.

${ }^{48} \mathrm{Hal}$ ini sesuai dengan prinsip pesantren, mengedepankan kesalehan spiritual, dan itu tercermin dalam sistem yang dikembangkan di Pondok Pesantren Miftahul Ulum Jatiroto Lumajang. 
Sesuai dengan observasi peneliti, adanya pembentukan kordinator mata pelajaran atau disebut Rois al-Qismi yang disertai gambaran umum tugas dan fungsinya. ${ }^{49}$

Zainuddin, kepala madrasah diniyah Miftahul Ulum mengatakan:

'Langkah yang dilakukan agar guru itu professional kami membentuk fan pelajaran. Dimana kelas 1 dan 2 fokus pada imlak, kelas 3 dan 4 Nahwu Shorrof dan kelas 5 dan 6 ilmu fiqh. Untuk kelas Tsanawiyah ilmu alat mantiq, balaghoh, ulumul Qur'an dan lain sebagainya.",50

Syahroni, Sekretaris Yayasan Pondok Pesantren Miftahul Ulum dalam wawancaranya mengatakan bahwa tujuan diadakannya fan pelajaran adalah untuk mengetahui dan menempatkan guru pada tempat yang sesuai dengan bidangnya. ${ }^{51}$

Dari beberapa paparan diatas, menunjukkan bahwasalah satu konsep profesionalitas guru di Madrasah Diniyah Miftahul Ulum Pondok Pesantren Miftahul Ulum Jatiroto Lumajang adalah membentuk fan pelajaran.

\section{Desain هِنْ الُْى sebagai perangkat pembelajaran}

مِنْ إلْىى merupakan sebuah jurnal mengajar yang dibuat oleh Madrasah Diniyah Miftahul Ulum Banyuputih Kidul, isi dari مِنْ إلُى tersebut seperti perangkat pembelajaran RPP. Kalau RPP adalah perangkat yang harus dibuat oleh setiap guru yang berada pada jenjang formal. Namun, هِنْ إلُى ini adalah jurnal yang sudah disiapkan oleh madrasah, artinya setiap guru dalam proses pembelajaran wajib mengikuti ketentuan yang sudah dibuat dalam panduan perangkat tersebut. ${ }^{52}$ Evaluasi terhadap guru dan siswa juga dilakukan setiap bulan.

Seperti hal dikatakan oleh Zainuddin, menurutnya:

"dalam mengkonsep guru profesional kami membuat sebuah jurnalyang didalamnya adalah sebuah rencana pembelajaransehingga guru tidak kebingungan lagi jika sampai pada waktu kuartal. Artinya guru tidak perlu bingung lagi jika sampai pada waktu kuartal materi belum sesesai. Dengan

\footnotetext{
49 Observasi, Madrasah Diniyah Miftahul Ulum.19 April 2018

50 Zainuddin, Wawancara, Kepala Madrasah Diniyah Miftahul Ulum, Kamis 19 April 2018.

${ }^{51}$ Syahroni, Wawancara, Sekretaris Yayasan Pondok Pesantren Miftahul Ulum, Kamis 19 April 2018.

52 Dokumentasi, Jurnal Madrasah Diniyah Miftahul Ulum 
adanya مِنْ إِلْى guru dapat mengetahui harus dimulai dari mana dan sampai dimana yang harus diselesaikan oleh guru materinya." 53

Dari hasil observasi yang dilakukan peneliti, ${ }^{54}{ }^{4}$ ơderupakanjurnal khusus untuk guru yang didalamnya terdapat batasan proses pembelajaran baik untuk guru maupun siswa di Madrasah Diniyah Miftahul Ulum Banyuputih Jatiroto Lumajang.

\section{Pembentukan Badan Pengelola Soal (BPS)}

BPS merupakan badan pengelola soal yang dibentuk oleh Madrasah Diniyah Miftahul Ulum Banyuputih Kidul, bertugas membuat soal-soal ulangan, kuartal maupun soal akhir. Badrut Tamam saat diwawancarai mengatakan:

"dalam mengkonsep agar guru menjadi profesional, kami melakukan musyawaroh dengan pihak Yayasan. Sehingga membuahkan hasil yaitu diadakannya pembentukan badan pengelola soal. Artinya ustadz difokuskan mengajar tanpa memikirkan tentang soal karena sudah ada tim yang membuat dan diwajibkan bagi seluruh asatidz untuk mengacu pada sِنْ إِلْى

Syahroni juga mengatakan bawah BPS dibentuk agar ustadz fokus dalam pembelajaran sesuai dengan batasan yang berlaku di madrasah. ${ }^{56}$ Dari hasil observasi peneliti, ${ }^{57} \mathrm{BPS}$ memiliki ruangan khusus yang tidak semua ustadz bisa masuk kedalam ruangan tersebut kecuali mereka yang sudah ditunjuk oleh madrasah sebagai tim badan pengelola soal.

Bahrul, salah satu asatidz Madrasah Diniyah Miftahul Ulum Banyuputih Kidul dalam wawancaranya:

'kami tidak membuat soal untuk ujian apapun, karena sudah ada yang membuatkan (BPS), kami hanya dituntut fokus pada hasil siswa dan dalam pembelajaran dengan mengacu pada مِنْ إلُْى , sehingga siswa tidak kebingungan dengan soal yang telah disiapkan oleh BPS." 58

53 Zainuddin, Wawancara, Kepala Madrasah Diniyah Miftahul Ulum, Kamis 19 April 2018.

54 Observasi, Madrasah Diniyah Miftahul Ulum.Kamis 19 April 2018.

55 Badrud Tamam, Wawancara, Waka KurikulumMadrasah Diniyah Miftahul Ulum, Kamis 19 April 2018.

56 Syahroni, Wawancara, Sekretaris Yayasan Pondok Pesantren Miftahul Ulum, Rabu 18 April 2018.

57 Observasi Madrasah Diniyah Miftahul Ulum, Rabu 18 April 2018.

58 Bahrul, Wawancara, Waka Kurikulum Madrasah Diniyah Miftahul Ulum, Kamis 19 April 2018. 
Dari hasil observasi dan paparan di atas dapat diketahui bahwa dengan membentuk BPS berarti membentuk guru menjadi profesional, karena guru hanya fokus pada pembelajaran siswa dan output dari siswa.

\section{Pengiriman Guru Tugas}

Pondok Pesantren Miftahul Ulum Banyuputih Kidul mempunyai program untuk mengirim santri ke berbagai wilayah, jika sudah lulus pada tingkat Tsanawiyah diniyah. Tingkat tsanawiyah diniyah merupakan tingkat diniyah tertinggi di pondok pesantren. Setelah tingkat tsanawiyah dikirim tugas selama satu tahun baru setelah itu dijadikan guru diniyah apabila santri tersebut layak.

H. Maksum, ketua Yayasan Pondok Pesantren Miftahul Ulum Banyuputih Kidul, mengatakan:

"untuk membentuk guru profesional di Madrasah Diniyah Miftahul Ulum ini, Pondok Pesantren sebagai institutsi di atasnya membuat program untuk mengirim santri ke berbagai wilayah baik dalam kota maupun luar kota. Untuk luar kota biasanya Madura dan Jakarta sebagai relasi dan jaringan pesantren kami. “ 59

Zainuddin, dalam wawancaranya menyampaikan:

"salah satu konsep profesionalitas guru adalah mengirim santri yang sudah lulus pada tingkat tsanawiyah diniyah ke tempat-tempat yang memang membutuhkan guru tugas. Alasannya agar santri dapat bersifat dewasa, dan mengetahui apa saja peran, fungsi, dan kewajiban seoarang guru madrasah diniyah, serta dapat belajar bersabar dan ikhlas. Sehingga nantinya setelah selesai melakukan tugas tersebut dapat menjadi guru madrasah diniyah disini dengan bekal ilmu yang sudah diperoleh dari tempat tugas."

Salah satu santri kelas tiga Tsanawiyah Diniyah, Muhammad Rofiudin, mengatakan:

'setelah kami lulus dari kelas III ini kami dikirim tugas ke berbagai tempat, dengan bekal dari Pondok Pesantren. Biasanya ketentuan yang diberlakukan di Pondok Pesantren Miftahul Ulum Banyuputih Kidul Jatiroto Lumajang adalah selama satu tahun"

59 Syahroni, Wawancara, Sekretaris Yayasan Pondok Pesantren Miftahul Ulum, Kamis 19 April 2018.

60 Zainuddin, Wawancara, Kepala Madrasah Diniyah Miftahul Ulum, Kamis 19 April 2018.

${ }^{61}$ Rofiudin, Wawancara, Siswa Madrasah Diniyah Miftahul Ulum, Kamis 19 April 2018. 
Hasil observasi yang dilakukan oleh peneliti, ${ }^{62}$ siswa yang telah dinyatakan lulus dari evaluasi belajar tahap akhir madrasah, ditandai dengan penerimaan ijazah sebagai bukti bahwa sudah dinyatakan lulus dan selanjutnya ditugaskan ke berbagai tempat di Jawa dan luar Jawa.

Dari keterangan tersebut menunjukkan bahwa program Pondok Pesantren dengan mengirim santri menjadi guru tugas di berbagai wilayah, merupakan sebuah konsep dasar agar guru di madrasah diniyah menjadi profesional. Dengan dikirim ke tempat lain santri dapat lebih dewasa dan mengerti cara bermasyarakat yang baik sebagaimana diajarkan di pondoknya. Setelah selesai menjalankan tugas mengajar selama setahun, ia akan diperkenankan menjadi nominator guru di Madrasah Diniyah tersebut.

\section{Mengikuti Tes Wawancara}

Tes wawancara merupakan salah satu persyaratan untuk menjadi guru di madrasah Diniyah Miftahul Ulum. Tes wawancara dilaksanakan setelah santri selesai tugas kemudian akan dijadikan sebagai guru di madrasah diniyah. Jika dalam tes wawancara lulus, dikatakan layak menjadi guru di madrasah diniyah, selanjutnya diadakan pembinaan dalam diklat halaqoh.

Samsul, Sekretaris Madrasah Diniyah saat diwawancarai mengatakan:

"agar pendidikan madrasah diniyah terjamin mutunya, maka gurunya juga harus bermutu. Dalam hal ini, kami membuat program untuk melakukan tes wawancara terlebih dahulu terhadap ustadz yang sudah melakukan tugas, dia layak atau tidak menjadi pengajar di madrasah diniyah."63

Mukhlis, salah satu pengajar di madrasah tersebut mengatakan:

'sebelum saya pribadi menjadi guru disini, setelah tugas dites terlebih dahulu melalui tes wawancara. Alasan dari madrasah ini adalah agar gurunya menjadi guru profesional sehingga pendidikan dan pembelajaran sesuai dengan tujuan yang diinginkan oleh madrasah." ${ }^{, 64}$

Keterangan diatas menunjukkan bahwa untuk menjaga mutu dan kualitas tenaga pengajar di Madrasah Diniyah Miftahul Ulum, tes wawancara adalah konsep masyarakat pesantren agar guru di madrasah diniyah menjadi profesional.

62 Observasi Madrasah Diniyah Miftahul Ulum Kamis 19 April 2018.

63 Samsul, Wawancara, Sekertaris Madrasah Diniyah Miftahul Ulum, Kamis 19 April 2018.

${ }^{64}$ Mukhlis, Wawancara, Kamis 19 April 2018. 


\section{Diklat Halaqoh}

Diklat Halaqoh adalah sebuah program Pondok Pesantren Miftahul Ulum mengadakan pertemuan yang didalamnya terdapat pembinaan bagi para pengajar. Pembinaan tersebut berisi pendidikan dan latihan dari pembina. Para pengajar tersebut sudah terbagi kedalam fan pelajaran. Biasanya Pondok pesantren mendatangkan salah satu alumni yang pernah menempuh pendidikan di luar negeri semisal Yaman, sebagai nara sumber.

Menurut Zainuddin, beliau mengatakan:

'kami mengadakan diklat halaqoh, sesuai dengan fan pelajaran. Misalkan fan pelajarannya tentang fiqh, maka diklat halaqohnya khusus fiqh. Begitu juga dengan fan yang lain. Kami mendatangkan salah satu alumni yang pernah mondok di Yaman sebagai narasumber. Karna menurut kami dia lebih faham tentang pengelolan kelas dan lain semacamya"

\section{Kesimpulan}

Konsep professionalitas guru dalam perspektif masyarakat pesantren di Madrasah Diniyah Miftahul Ulum Banyuputih Kidul Jatiroto Lumajang adalah kedewasaan bersikap, loyalitas tinggi dan pakar keilmuan.

Sikap dewasa di sini mengandung makna banyak hal. Di antaranya menjadi teladan, sabar, disiplin, bijak dalam mengambil keputusan, dan lain sebagainya. Kedewasaan bersikap yang dipandang oleh masyarakat pesantren merupakan sosok guru profesional. Loyalitas tinggi merupakan santri maupun alumni yang berprofesi sebagai guru di madrasah diniyah Miftahul Ulum tanpa digaji atau dapat juga dikatakan sebagai pengabdian. Pakar keilmuan disini adalah pemfokusan terhadap mata pelajaran sesuai dengan bidang masing-masing, sehingga para guru di madrasah diniyah Miftahul Ulum terfokus pada yang dibidangi saja.

Implementasi Profesionalitas Guru di Madrasah Diniyah Miftahul Ulum Banyuputih Kidul adalah dengan Adanya pembentukan fan pelajaran, adanya مِنْ إلْىى, Pembentukan Badan Pengelola Soal (BPS), dikirim tugas terlebih dahulu, mengadakan Diklat Halaqoh dan pemberlakuan tes wawancara. 


\section{Referensi}

Arikunto, Suharsimi. 2003. Prosedur Penelitian, Jakarta: PT. Rineka Cipta.

Asmani, Jamal Ma'mur. 2012. Pendidikan Berbasis Keunggulan Lokal, Jogjakarta: Diva Press.

Aziz, Hamka Abdul. 2016.Karakter Guru Profesional, Jakarta: AMP Press.

Azra, Azyumardi. 1999. Pesantren Kontinuitas dan Perubahan, Jakarta: Nirmana Media.

Buchori, Mochtar. 2011. Guru Profesional dan Mutu Pendididkan, Jakarta:Uhamka Press.

Djamaludin. 1999. Kapita Selekta Pendidikan Islam, Bandung: CV. Pustaka Setia.

Djamarah, Syaiful Bahri. 1994. Prestasi Belajar Dan Kompetensi Guru, Surabaya: Usaha Nasional.

Echol, Jhon M. 1982. Kamus Inggris Indonesia, Jakarta: Gramedia.

Hasbullah. 1999. Sejarah Pendidikan Islam di Indonesia, Jakarta: Raja Grafindo Persada.

Kartini, Kartono. 1996. Metodologi Penelitian Sosial, Bandung: Bumi Aksara.

Madjid, Nurcholish. 1997. Bilik-Bilik Pesantren Sebuah Potret Perjalanan, Jakarta: Paramadina.

Maksum. 2003. Pola Pembelajaran Dipesantren, Jakarta: Departemen Agama.

Moeleong, Lexy J. 1994. Metode penelitian kualitatif, Bandung: Remaja Rosda Karya Offest.

Mulyasa. 2006. Menjadi Guru Profesional, Bandung: Remaja Rosda Karya.

Mulyasa. 2011. Standar Kompetensi Dan Sertifikasi Guru, Bandung: Remaja Rosda Karya.

Noor, Rohiah M. 2010. KH Hasyim Asy'ari Memodernisasi NU \& Pendidikan Islam, Jakarta: Grafindo Khazanah Ilmu.

Peraturan Menteri Pendidikan Nasional Republik Indonesia No 16 Tahun 2007.

Ramayulis. 2010. Ilmu Pendidikan Islam, Jakarta: Kalam Mulia.

Rosyada, Dede. 2017. Madrasah Dan Profesionalisme Guru, Depok: Kencana.

S, Margono. 2000. Metodologi Penelitian Pendidikan, Jakarta: Rineka Cipta.

Safroni, M. Ladzi. 2013. Al-Ghazali Berbicara Tentang Pendidikan Islam, Malang: Aditya Media.

Sarkowi. 2011. Labirin Pendidikan Islam, Malang: Resist Literacy.

Sunarto, Ahmad. Tt. Ta'limul Muta'allim,Surabaya: Alhidayah.

Supriadi. 2006. Etika Dan Tanggung Jawab Profesi Hukum Di Indonesia, Jakarta: Sinar Grafika.

Suteja. 1999. Pola Pemikiran Kaum Santri, Bandung: Pustaka Hidayah. 
Syatra, Nuni Yusvavera. 2013. Desain Relasi Efektif Guru Dan Murid, Jogjakarta: Buku Biru.

Uzer, Moh. Usman. 1991. Menjadi Guru Profesional, Bandung: Remaja Rosdakarya.

UU Guru dan Dosen No. 14 Th. 2005. BAB IV Pasal 10 Ayat 1.

Ziemik, Manfred. 1986. Pesantren Dalam Perubahan Sosial, Jakarta: P3M. 